No. $14(18)$

\title{
STATYSTYKA W XXI WIEKU. PRZYSZLOŚĆ STATYSTYKI
}

\begin{abstract}
Antoni Smoluk
DOI: $10.15611 / \mathrm{dm} .2017 .14 .06$

Uwagi niniejsze są pokłosiem konferencji1 ${ }^{1}$, która odbyła się we Wrocławiu z okazji stulecia Polskiego Towarzystwa Statystycznego.

Dziękuję organizatorom, Katedrze Statystyki Uniwersytetu Ekonomicznego we Wrocławiu oraz wrocławskiemu oddziałowi Głównego Urzędu Statystycznego, za zaproszenie.

Dobra inicjatywa, perfekcyjna organizacja, szerokie spektrum programowe - bardzo potrzebne spotkanie. Byli oficjele, było „mnogoludno”, były mowy okolicznościowe, listy gratulacyjne, medale, dyplomy, nagrody, była refleksja nad czasem minionym - ocena dokonań, były próby zarysowania statystyki przyszłości. Statystyka jest nauką o pomiarze stanów natury zależnych od działalności człowieka, jest to rodzaj antropologii społecznej. Jak decyzje indywidualne wpływają na populację? Jakość statystyki jest silną pochodną jakości społeczeństwa - jego troski o zbiorowość, poczucia wspólnoty, kultury ogólnej, dyscypliny, wiedzy, wykształcenia i wychowania. Podstawą statystyki jest probabilistyka - nauka o wypukłości, rachunek losów: tak poetycznie nazywa się czasami rachunek prawdopodobieństwa. Nauka ta wyrosła z gier losowych, aliści jest wiedzą pewną. Jej niezwykłość polega na tym, iż przypadek i możliwość zamienia w determinizm. Możliwość staje się koniecznością wyższego rzędu - miarą unormowaną na jeden; całość - to
\end{abstract}

\footnotetext{
Antoni Smoluk

Wrocław University of Economics

email: math@ue.wroc.pl

ORCID: 0000-0002-9990-037X
}

${ }^{1}$ Notka ta jest przeredagowanym listem, który został opublikowany w ocenzurowanej wersji w sprawozdaniu z konferencji poświęconej 100 rocznicy Polskiego Towarzystwa Statystycznego. Ponadto jest on ukryty w sprawozdaniu z konferencji, nie ma go w spisie rzeczy i trudno go odnaleźć w tej publikacji [Smoluk 2012]. Moje uwagi mogą zainteresować szersze grono, więc myślę, że warto je rozpowszechnić. Dołączam także fragmenty nowe: krytykę testów statystycznych oraz złotą regułę, użyteczną przy opracowywaniu ankiet. 
naturalnie $100 \%$. Prognozą naukową jest rozkład - prawo nauki. Jest to wypowiedź pewna o całej populacji. Co się wydarzy, tego nauka nie wie; nauka nie podaje, co wypadnie na loterii - jakie liczby pojawią się w okienku. Rozkład - miara probabilistyczna - jest wiedzą naukową pewną, chociaż całkowicie nieprzydatną w wypełnianiu kuponów gier losowych. Przypuszczalnie istnieje wiedza pełna, dostępna wybrańcom, która pozwala widzieć przyszłe zdarzenia. Nie jest to nauka, lecz objawienie, a ludzi z takim darem uważa się za świętych. Realizacja rozkładu, konkretna liczba, nie jest prognozą naukową. Tylko rozkład jest nauką, a wartość praktyczna tej wiedzy jest różna. Prognoza naukowa jest pewna, ale wynik realizacji zdarzenia jest wątpliwy. Konkretem - realizacjami - zajmuje się statystyka. Prawdopodobieństwo klasyczne w skończonej mnogości - zdarzenia elementarne są jednakowo uprzywilejowane - czasami jest prawem nauki, czasami roboczą hipotezą. Prawo wielkich liczb redukuje prawdopodobieństwa do statystyki: prawdopodobieństwa to częstości, procenty. Celem nauki jest doskonałość.

Wielkość przybliżona jest przedziałem, rozkład jednostajny jest także przedziałem. Jest to rozkład symetryczny, ograniczony o skończonej wariancji, którego moda idealna jest równa naturalnie średniej. Podstawą statystyki jest więc rozkład jednostajny. Proponuję konkurs na dzieło ujmujące statystykę w taki właśnie sposób, z punktu widzenia rozkładu jednostajnego. Byłaby to swoista uniformizacja tej nauki istotnie upraszczająca wykład; przy okazji można wyeliminować wiele bytów zaludniających książki statystyczne, a bez wartości praktycznej. W tym jak na razie wirtualnym podręczniku są tylko wypukłe, skończone kombinacje - mieszanki - rozkładów jednostajnych. Oczywiście zbiór mieszanek jest gęsty w przestrzeni metrycznej wszystkich rozkładów z odległością całkową. Uniformizacja statystyki - to zadanie dla mądrego i odważnego probabilisty. Jeśli dobrze namalujesz sosnę, usłyszysz szum wiatru w jej gałęziach; jeśli dobrze wyłożysz statystykę, zobaczysz jej piękno i użyteczność. Celem nauki jest doskonałość.

Sprawozdawczość jest wszędzie, więc statystyka jest tak samo wszędzie. Marketing i reklama zostały w ostatnich latach wzbogacone o dodatkową statystykę - probabilistyczną sprzedaż. W markecie na wybrany towar nie ma jednej ceny, lecz jest rozkład cen. Można kupić tanio lub drogo - cena ciągle drga w czasie i przestrzeni. Taka polityka cenowa profituje - przyciąga klientów. Jedną rzecz sprzeda się niżej wartości, inną z nadwyżką, a średnio wychodzi się na swoje. 
Świat współczesny klasyfikuje i porównuje; benchmark jest modny. Wybiera się najładniejszą dziewczynę, najsprawniejszą piłkarską drużynę, najszybszy samochód, najlepszą uczelnię. Tworzymy liniowe porządki w zbiorach, gdzie naturalnych porządków nie widać. Jakość mierzą preferencje lub funkcje użyteczności. Czy są to narzędzia subiektywne? Świat potrzebuje indeksów, bo one właśnie mają obiektywizować decyzje, zdejmować odpowiedzialność. Jest to swoisty raj liczbowy - data mining. Dobrze zorganizowane jest to społeczeństwo, w którym ludzie czują się szczęśliwi. Nie liczby decydują, lecz serce i szczęście. Podobnie jest z uczelniami - dobra uczelnia kształci światową elitę. Siłę ciężkości czy pole magnetyczne można zmierzyć. Jak porównywać ryż z pszenicą? Co jest lepsze? Chociaż indeksy nie mają charakteru obiektywnych mierników, życie je wymusza. Powszechną metodą tworzenia preferencji są ankiety i głosowania. Liczby - częstości dają porządek liniowy: pozorną obiektywność - Nirvana by numbers, bo przecież wyniki głosowań są obciążone. Chcemy zwykle zaprezentować się $\mathrm{z}$ lepszej strony, więc na pokaz robimy co innego, niż myślimy. Z tej właśnie przyczyny potrzebna jest statystyka behawioralna, która wyeliminuje błędy pomiaru. Ankieter nie pyta o ocenę, lecz sam ocenia na podstawie obserwacji w określonej sytuacji decyzyjnej. Badania behawioralne nie są łatwe i też są obciążone; błąd zależy od wiedzy i doświadczenia obserwatora. Nie absorbują jednakowoż badanego, bo robi się je bez jego wiedzy. Jest to rodzaj statystycznego szpiegowania. Statystyka behawioralna ma przyszłość, kryje się w niej wielka potencja informacyjna; najpierw jednak trzeba przygotować wywiadowców - obserwatorów. Celem nauki jest przecież doskonałość.

Żyjemy w wieku rewolucji informatycznej. Czy statystyka w tych warunkach jest łatwiejsza? Zdjęcia satelitarne pokazują cały glob: pola, lasy, wsie i miasta. Widzimy każdy dom, można zinwentaryzować stan gospodarki: zasiewy, drogi, komunikację i budownictwo. Ponadto jest teoretyczna możliwość śledzenia wszystkich członków populacji z użyciem bransoletynadajnika - takiego statystycznego zegarka. W czasie ciągłym centrum jest informowane o stanie zdrowia i miejscu pobytu właściciela. Niewątpliwe ograniczenie wolności osobistej skutkuje pełnym opisem i bezpieczeństwem zbiorowości. Definiuje firmy - wspólne miejsca pracy. Można też centralnie kierować ruchem drogowym - dyspozytor przez wbudowany w pojazd komputer określa optymalną prędkość i wybiera trasę. Tak samo może być $\mathrm{z}$ każdą firmą i gospodarstwem domowym - centrum określa poziom życia i jakość konsumpcji. 
Decyzją jest element zbioru, jeśli w mnogości tej jest zadana preferencja lub jest określona funkcja użyteczności. Większość decyzji, szczególnie decyzji finansowych, to rozkłady. Jakie mogą być preferencje w rodzinie rozkładów o wspólnej średniej? W rodzinie rozkładów jednostajnych dobrą funkcją użyteczności jest wariancja. Dla innych rozkładów ograniczonych, dla których istnieje przedział domknięty o mierze 1, już nie widać prosto określonej funkcji decyzyjnej. Statystyka rządzi demografią, finansami, ubezpieczeniami wszelkiego rodzaju i oczywiście polityką. Statystyka jest pomiarem specyficznym - wynikiem pomiaru jest rozkład. Subiektywnego wyboru statystycznych decyzji nie da się pewnie całkowicie zobiektyzować; każdy stan jest zawsze optymalny przy odpowiednim kryterium i zawsze nieoptymalny - gdy zmienimy ocenę. Obiektywnego natężenia jakości nie ma i być nie może, bo właśnie jakość jest odczuciem subiektywnym, chociaż niewątpliwie wybór przeciętny jakoś ją obiektywizuje. Teoria preferencji w rodzinie rozkładów jest istotą statystyki; porównujemy miary - nie liczby.

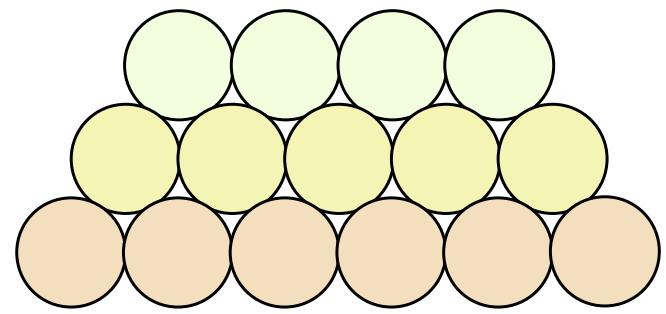

Rys. 1. Pielęgnacja sherry

Źródło: opracowanie własne.

Sherry - napój szczególnie ceniony w Anglii - zalicza się do win południowych, słodkich, mocnych i ciężkich. Leżakuje ono w wysokiej temperaturze półwyspu hiszpańskiego wiele lat. Beczki układa się warstwowo, a poziomów jest kilka - przynajmniej trzy, tak że tworzą one wycinek struktury trójkąta Pascala albo deski Galtona (rys. 1). Wystałe wino odciąga się z dolnej warstwy, a niedobór w beczkach niższego poziomu uzupełnia się płynem z warstwy wyższej - dokładnie tak, jak tworzy się współczynniki dwumianowe albo jak sypki materiał spływa po desce Galtona. Jest to zarazem technologiczny proces uszlachetniania napoju przez mieszanie. Beczki warstwy górnej - najwyższej - zalewa się młodym winem. Niższa beczka - pomijając skrajne - jest dokarmiana przez dwie, lewą i prawą, wyższe. Sherry rodzi się więc zgodnie z rozkładem dwumianowym. Hugo Steinhaus proponował budować mosty wiszące z kratownic kształtu heksagonalnego. Sześciokąty - 
odpowiedniki kół (rys. 1) - pokrywają naturalnie całą płaszczyznę i przenoszą naciski punktowe na jezdnię równomiernie na łuk podtrzymujący most. Jest to proces odwrotny - dekumuluacja współczynników dwumianowych na składniki podstawowe, czyli wyjście na brzeg trójkąta Pascala. Tyle o związku probabilistyki z enologią. Teraz przejdźmy do geografii i rzek. Rzeki komunikują, żywią, tworzą cywilizacje. Rzeka to woda - bez wody nie ma życia, rzeka to fundament cyklicznego obiegu wody w przyrodzie. Niektóre rzeki kończą swój bieg intrygującym zjawiskiem przyrodniczym i geograficznym - deltą. Trójkąt Pascala też ma kształt delty i narasta w taki sam kumulatywny sposób jak delta rzeczna. W Europie niezwykłą deltą zanika Wołga; słyną również w tej materii Dunaj oraz Rodan. Inne znane delty to ujścia Nilu, Amazonki, Missisipi i Gangesu. Czy wzrost delty jest istotnie zgodny z rozkładem dwumianowym? Teza ta - jak na dziś - jest tylko hipotezą. Może zajmie się tym potamografia - najpiękniejsza część geografii. Na koniec fizyka i falowanie. Fala jest równie piękna jak rzeka. Rzeka przenosi energię wraz z materią, fala - bez materii. Każdy podziwiał kręgi na wodzie; jest to fala płaska. Dowolny punkt czoła fali jest źródłem fali. Podejrzewam, że fale, nakładając się, tworzą front zgodnie z rozkładem dwumianowym. Trójkąt Pascala jest pięknym powszechnym prawem nauki. Symetria jest odbiciem operacji dopełniania zbiorów; w świecie skończonym dopełnienia podzbiorów równolicznych są wzajemnie równoliczne i naturalnie jest ich tyle samo co zbiorów dopełnianych. W trójkącie Pascala łączy się nauka o fraktalach $\mathrm{z}$ równowagą ośrodków płynnych i sypkich. W każdym punkcie brzegu delty tworzy się nowa delta, a całość rośnie ameboidalnie. Falowanie morza wyrównuje brzeg, interferencja fal tworzy nowy front - czoło fali.

\section{Petit à petit l'oiseau fait son nid.}

Ziarnko do ziarnka, a zbierze się miarka. Matematyka jest abstrakcyjnym szkieletem wszelkiej nauki, a statystyka jest metrologią społeczną - nauką o średnich, czyli teorią miary i całki. Celem nauki jest przecież doskonałość.

Przed statystyką globalną widzę jasną przyszłość. Statystyka przyszłości związana będzie niewątpliwie z geografią i ekologią. Śledzić będziemy stan zlodowacenia globu, pustynnienie kontynentów, ewidencjonować rośliny i zwierzęta. Również rozwój aglomeracji miejskich będzie monitorowany. Miasta mają stać się przestrzenią sprzyjającą mieszkańcom, a nie molochem przemysłowym czy sypialnią. Przyszłość ludzkości jednak widzi się w ciemnych kolorach, współczesne tendencje rozwojowe bowiem zmierzają do tworzenia skupisk ludzkich na wzór kolonii termitów czy mrowisk. 
Obszerna część statystyki i rachunku prawdopodobieństwa traktuje o testowaniu hipotez. Jest to nauka pozorna o niczym. Prawa nauki weryfikuje się empirycznie, niekiedy decyduje utylitaryzm. Ta teoria jest akceptowana, która w danej chwili przynosi większy zysk - jest bardziej użyteczna. Implikacja: jeśli $p$, to $q$, jest prawdziwa zawsze, gdy zdanie $p$ jest fałszywe, niezależnie od wartości logicznej zdania $q$. Jeśli jednak zdanie $p$ jest prawdziwe, wtedy koniecznie zdanie $q$ musi być również prawdziwe, aby implikacja była prawdą.

W statystyce z prawdziwości zdania $q$ wnosi się o prawdziwości zdania $p$. Jest natomiast odwrotnie - jeśli $p$ jest prawdą, to $q$ jest prawdą, jeśli natomiast $q$ jest prawdą, to $p$ może być zarówno prawdą, jak i fałszem. Czy $p$ jest prawdą, tego nigdy nie wiemy. Oczywiście, że wartość naukową mają twierdzenia tyczące się miar lub rozkładów, lub zmiennych losowych. Jeżeli miara jest dana, to wynikiem naukowym jest twierdzenie, że określona funkcja od tej miary jest jakąśs specyficzną miarą. Naturalnie miara oznacza tutaj prawdopodobieństwo. Wykorzystanie tego typu twierdzeń w testowaniu hipotez statystycznych jest czystym nadużyciem, bo ta miara nie jest znana. Mamy tylko próbę i na podstawie tych prób możemy obliczyć parametry empiryczne. Jakich miar one dotyczą, tego nigdy nie wiemy. Prawa nauki zawsze formułuje się intuicyjnie na podstawie informacji empirycznych, a weryfikuje, prognozując. To jest prawdą, co jest zgodne z naturą. Nauka jest zawsze o obiektywnie istniejącym świecie fizycznym. Rozważania o niczym są czystą intelektualną zabawą i niczym więcej. W niektórych dziedzinach nauki, szczególnie w medycynie, testy statystyczne stały się obowiązującą regułą. Praca jest uważana za naukową wtedy tylko, gdy jej autor korzysta przynajmniej z jednego testu. A przecież wiadomo, że żaden test nie podniesie jakości danych i nie zwiększy liczby eksperymentów - wykorzystanych przypadków. Litter in - litter out. Dasz śmieci na wejściu - śmieci otrzymasz także na wyjściu. Testy tu nic nie pomogą. Zamiast tworzyć testy statystyczne, proponuję pracować nad nowymi testami inteligencji. Ze zbioru trzech niejednakowych kwadratów daje się ułożyć prostokąt. Jaki jest stosunek boku krótszego do dłuższego w tym prostokącie? Tego typu zadań brakuje w obecnie funkcjonujących testach inteligencji. Rozwiązaniem tego zadania jest liczba $2 / 3$. Pojawia się tutaj również niespodziewanie reguła 2/3, o której piszę więcej niżej. Jeżeli ze zbioru czterech kwadratów da się ułożyć prostokąt, to jaki jest stosunek boku krótszego do dłuższego w tym prostokącie? Odpowiedzi nie podaję. Jeżeli czytelnik poda wszystkie możliwe przypadki w czasie krótszym niż jedna minuta, to jego inteligencja jest na najwyższym poziomie. Przy okazji wspomnę o pięknym twierdzeniu związanym z układaniem prostokątów z kwadratów. 
Jeżeli ze skończonego zbioru kwadratów da się ułożyć prostokat, to boki tych kwadratów sq wspótmierne. W twierdzeniu tym nic się nie mówi o bokach. Mogą być klasy kwadratów mających taki sam bok. Odcinki $a$ i $b$ są współmierne, jeśli istnieje odcinek $c$ taki, że $a=m c$ i $b=n c$, gdzie $m$ i $n$ to odpowiednie liczby naturalne. Współmierność odcinków okazuje się liniową zależnością w przestrzeni liniowej liczb rzeczywistych $R$ nad ciałem liczb wymiernych $Q$. Ta przestrzeń ma wymiar nieskończony; liczby niewymierne - pierwiastek kwadratowy z dwóch i pierwiastek kwadratowy z trzech - są $\mathrm{w}$ tej przestrzeni liniowo niezależne.

Czym jest ułamek łańcuchowy? Jest to algorytm pozwalający znaleźć dla dwóch danych odcinków $a$ i $b$ odcinek $c$ będący ich wspólną miarą. Jeśli odcinki nie są współmierne, algorytm nie zatrzymuje się. Powstaje ułamek łańcuchowy, którego wartością jest stosunek odcinka krótszego do dłuższego. Aby zbadać współmierność trzech odcinków, należy najpierw zbadać współmierność dwóch, a następnie współmierność ich wspólnej miary, gdy są współmierne z trzecim odcinkiem. W przypadku większej liczby odcinków postępuje się analogicznie.

Skończony zbiór kwadratów ma boki współmierne wtedy i tylko wtedy, gdy ze zbioru tego, z dokładnością do rozkroju, da się ułożyć prostokąt. Rozkrojem zbioru kwadratów jest podział niektórych kwadratów tej rodziny na mniejsze jednakowe kwadraty: 4, 9, 16 itd. Kwadraty nie muszą być dzielone na jednakową liczbę części. Różne długości boków - zakładamy, że jest ich $k+1$ - oznaczone są literą $x \mathrm{z}$ indeksem, zaczynającym się od $0 \mathrm{i}$ biegnącym aż do $k$. Liczby te silnie rosną: najmniejsza z nich ma numer zero, a największa $k$. Oczywiście różnych długości boków jest nie więcej niż wszystkich kwadratów, których jest $n+1$. Jeśli z kwadratów tych ułożymy prostokąt o bokach $a$ i $b$, to prostokąt ten wyznacza punk płaszczyzny $(a, b)$. Niech punkt $c$ leży pomiędzy 0 i $a$. Prosta $x=c$ przecina prostokąt. Punktowi $c$ odpowiada równanie $f(c)=b$, gdzie $f(c)$ jest sumą tych boków, które kwadraty przecina prosta $x=c$. Analogicznie otrzymuje się równanie $g(d)=a$, dla każdego $d$ leżącego pomiędzy 0 i $b$. Prostokąt jest podzielny, jeśli istnieje takie $c$ we wnętrzu odcinka $[0, a]$, że prosta $f(c)=b$ nie przecina wnętrza żadnego kwadratu, lub gdy istnieje takie $d$ we wnętrzu odcinka $[0, b]$, że prosta $g(d)=a$ nie przecina także wnętrza żadnego kwadratu. Jest to rozkładalność ze względu na oś $x$-ów lub ze względu na oś $y$-ów. Prostokąt jest rozkładalny, gdy jest rozkładalny ze względu na oś $x$-ów albo ze względu na oś $y$-ów. Układ równań $f(c)=b$ i $g(d)=a$ jest niesprzeczny i ma jednoznaczne rozwią- 
zanie. Oczywiście boki prostokąta $a$ i $b$ to sumy niektórych boków kwadratów. Najkrótszy bok kwadratów traktuje się jako wielkość daną, a pozostałe wylicza się z równań liniowych o współczynnikach całkowitych. Ten układ jest niesprzeczny i oznaczony. Rozwiązania, czyli długości pozostałych boków, wyrażają się przez bok najkrótszy xo ze współczynnikiem wymiernym.

Zastąpienie dowolnego kwadratu w danym układzie kwadratów kwadratami mniejszymi w liczbie naturalnie 4, 9, 16 lub więcej nie zmienia współmierności boków kwadratów. Spostrzeżenia te - zakładamy, że prostokąt jest niepodzielny i dowolny kwadrat można podzielić na mniejsze kwadraty - potwierdzają wypowiedź o jednoznaczności rozwiązania zredukowanego układu równań; redukcja sprowadza się do wykreślenia, wszystkich równań jest nieskończenie wiele, równań identycznych lub zależnych od pozostałych.

Boki kwadratów są współmierne wtedy i tylko wtedy, gdy podprzestrzeń liniowa rozpięta na ich długościach ma wymiar $1 \mathrm{w}$ przestrzeni liniowej $R$ liczb rzeczywistych nad ciałem $Q$ liczb wymiernych. Rzędem niewspółmierności skończonego zbioru odcinków jest wymiar podprzestrzeni liniowej, pomniejszony o 1, rozpiętej na długościach tych odcinków w przestrzeni liniowej $R$ nad ciałem $Q$. Rząd niewspółmierności 0 oznacza, że odcinki są współmierne. Rząd niewspółmierności jest więcej niż analogonem, jest dokładnym odpowiednikiem rzędu macierzy.

Boki skończonego układu kwadratów są współmierne wtedy i tylko wtedy, gdy podprzestrzeń liniowa rozpięta na ich długościach ma wymiar $1 \mathrm{w}$ przestrzeni $R$ nad $Q$. Myśl tę powtarzamy repetitio est mater studio rum. Współmierność jest liniową zależnością. Algebra staje się geometrią, a geometria algebrą.

Ciągiem Euklidesa nazywa się taki ciąg liczb naturalnych, którego pierwszy wyraz jest różny od 0 , a jeśli jakiś wyraz jest 0 , to również wyraz następny jest 0 . Pierwszy wyraz ciągu ma zawsze numer 0. Jeżeli w ciągu Euklidesa występuje wyraz równy 0 , to taki ciąg nazywa się ciągiem skończonym skończona liczba wyrazów w tym ciągu jest różna od 0 i wyrazy różne od 0 występują kolejno, nie są przedzielone zerami.

Prostokąt to punkt $(a, b)$ leżący w pierwszej ćwiartce taki, że $a+b$ nie jest 0 . Jeżeli $a=b$, to prostokąt jest naturalnie kwadratem. Jeśli jeden z boków jest 0 , to zdegenerowany prostokąt jest odcinkiem. Jeśli bok $a$ jest silnie większy od boku $b$, wtedy mówimy o prostokącie horyzontalnym, a gdy $b$ jest silnie większe od $a$ - o wertykalnym.

Z każdego prostokąta niezdegenerowanego do odcinka możemy odcinać kwadraty o boku równym krótszemu bokowi prostokąta tak długo, aż prostokąt horyzontalny stanie się wertykalnym lub wertykalny - horyzontalnym; trzecią 
możliwością jest podział całego prostokąta na kwadraty bez reszty. Liczba kwadratów odciętych z prostokąta w odpowiednim kroku jest wyrazem ciągu Euklidesa; jeśli w którymś kroku nie ma reszty z podziału prostokąta na kwadraty, wtedy wszystkie dalsze wyrazy tego ciągu są zerami. Prostokąt niezdegenerowany definiuje jakiś ciąg Euklidesa. Prostokąty podobne, o bokach proporcjonalnych, definiują ten sam ciąg Euklidesa. Kwadratowi odpowiada ciąg Euklidesa, którego pierwszy wyraz jest jednością, a wszystkie pozostałe zerami.

Ciąg Euklidesa definiuje ułamek łańcuchowy, zwany również ułamkiem ciągłym. Czym jest ułamek łańcuchowy? Jest to algorytm geometryczny znajdywania odcinka będącego wspólną miarą dwóch danych odcinków tworzących boki prostokąta. Ten algorytm jest opisany w rozkroju prostokąta na kwadraty. Jeżeli otrzymany ciąg Euklidesa jest skończony, to odcinki są współmierne, a wspólną miarą jest bok najmniejszego kwadratu. Jeżeli natomiast odcinki są niewspółmierne, to ciąg Euklidesa nie jest skończony, algorytm nigdy się nie kończy - obcinamy coraz mniejsze kwadraty ad infinitum. Ułamek łańcuchowy naturalny, zwany dalej krótko ułamkiem łańcuchowym, jest ciągiem funkcji odwzorowujących zbiór liczb rzeczywistych nieujemnych w siebie. Funkcje te są określone przez ułamki; w liczniku jest 1, a w mianowniku odpowiedni wyraz ciągu Euklidesa plus zmienna oznaczająca argument funkcji, gdy wyraz ciągu Euklidesa jest różny od zera, a gdy ten wyraz jest zerem, to odpowiadająca mu funkcja przyjmuje stale wartość zero. Ułamek łańcuchowy jest właściwie ciągiem superpozycji wyżej określonych funkcji; pierwsza funkcja w ciągu superpozycji jest bez zmiany, drugą jest superpozycja pierwszej z drugą, trzecią superpozycja pierwszej, drugiej oraz trzeciej itd. Wartości tych superpozycji wzięte w punkcie zero nazywają się reduktami ułamka łańcuchowego. Redukty są więc ciągiem dodatnich ułamków właściwych, tylko pierwszy redukt może być jednością, gdy ciąg reduktów nie jest stacjonarny. Redukty są więc liczbami wymiernymi. Podciąg ciągu reduktów o numerach parzystych jest ciągiem malejącym, a podciąg ciągu reduktów o numerach nieparzystych jest ciągiem rosnącym. Ciągle pamiętać należy, że wyrazy wszystkich ciągów numeruje się od zera i że zero jest liczbą parzystą. Ciąg reduktów ma więc dolną granicę i górną granicę. Jeśli te granice są równe, wtedy jest zbieżny. Granicą ułamka łańcuchowego wyznaczonego przez ciąg Euklidesa otrzymany z podziału prostokąta jest ułamek będący stosunkiem boku krótszego do dłuższego w tym prostokącie. Jeżeli ciąg Euklidesa jest skończony, to ciąg reduktów jest zbieżny i boki są współmierne. Granicą takiego ciągu jest redukt odpowiadający ostatniemu wyrazowi ciągu Euklidesa różnemu od zera. Wartością ułamka łańcuchowego jest granica, gdy istnieje, ciągu reduktów. 
Prostokąt złoty to taki prostokąt, z którego w każdym kroku odcina się tylko jeden kwadrat. Liczba złota jest ułamkiem niewymiernym będącym stosunkiem boku dłuższego do krótszego w prostokącie złotym. Prostokątowi złotemu odpowiada ciąg Euklidesa, którego wszystkie wyrazy są jedynkami. Redukty prostokąta złotego są ułamkami; w liczniku jest wyraz ciągu Fibonacciego i w mianowniku też jest wyraz ciągu Fibonacciego, tylko o jeden numer dalszy. Tak więc liczba złota jest ukryta w ciągu Fibonacciego i definiuje ją proces rozmnażania się królików i wiele innych zjawisk przyrody opisywanych przez ten ciąg.

Jakość jest preferencją, czyli relacją zwrotną i przechodnią. Jak mierzyć jakość? Istnieje teoria funkcji użyteczności, których używa się do kwantyfikacji relacji preferencji; odwrotnie - funkcja użyteczności definiuje relację preferencji. Eksperymentem, na podstawie którego wyznacza się relacje preferencji i funkcje użyteczności, są ankiety. Dana jest więc pewna liczba ankiet, czyli relacji preferencji; na tej podstawie należy zbudować preferencję grupową, obiektywizującą poglądy indywidualne. Robi się to na różne sposoby - albo wybiera się środek ciężkości specjalnie zdefiniowany, albo tworzy się relację opartą na maksymalnych częstościach, albo postępuje się całkiem inaczej. Jeżeli preferencje dotyczą określonej grupy towarów, to słowo $a b$ nazywa się decyzją lub zdarzeniem; oznacza ono, że towar $a$ preferujemy nad towar $b$. Oczywiście jedna i ta sama osoba może podejmować dwie decyzje z pozoru różne $a b$ i $b a$, oznaczające równoważność towaru $a \mathrm{z} b$. Zdarzenie jest utożsamiane ze zbiorem tych osób, które podjęły odpowiednią decyzję. Jeżeli preferencja jest porządkiem, wtedy takie decyzje nie są możliwe przy różnych towarach: albo jest $a b$, albo ba. Częstotliwością decyzji jest stosunek liczby preferencji uznających tę decyzję do liczby wszystkich preferencji. Częstotliwość można więc uważać za procent uczestników ankietowanych podejmujących tę decyzję. Relacją maksymalną jest relacja utworzona z tych decyzji, których częstotliwości są maksymalne. Relacja maksymalna może być preferencją, ale może i nią nie być.

Lemat. Jeżeli zdarzenia A i B maja jednakowe prawdopodobieństwo $p i$ zdarzenia te sa niezależne oraz prawdopodobieństwo iloczynu tych zdarzeń jest ostro większe od $1-p$, to p jest większe od liczby złotej chi.

Dowód tego lematu, zwanego forcingiem probabilistycznym, jest prosty. Przypomnę tylko, że liczba złota jest średnią arytmetyczną pierwiastka kwadratowego z 5 i liczby minus jeden. Z lematu wynika złota reguła, sformułowana niżej. Zdarzenia nazywamy częstotliwościowo niezależnymi, jeżeli 
częstotliwość iloczynu zdarzeń jest większa lub równa iloczynowi częstotliwości tych zdarzeń. Lemat powyższy można odwrócić. Jeśli zdarzenia są niezależne oraz częstotliwość każdego z nich jest ostro większa od liczby złotej, to częstotliwość iloczynu tych zdarzeń jest ostro większa od dopełnienia do jedności liczby złotej.

Twierdzenie. Jeśli preferencje sa porządkami liniowymi, każda decyzja maksymalna ma częstotliwość silnie większa od chi i zdarzenia tworzace relację maksymalna sa częstotliwościowo niezależne, to relacja maksymalna jest porzadkiem liniowym.

Twierdzenie to właśnie nazywa się złotą regułą. Jest to idealizacja, rozszerzenie i rektyfikacja reguły 2/3 Janusza Łyki. W regule profesora Łyki mówi się o preferencjach [Łyko 2000]. Ciekawostką jest fakt, że z reguły Titiusa i Bodego, tyczącej się wzajemnych odległości planet naszego układu słonecznego, wynika kosmiczna reguła 2/3. Jeżeli planety A, B, C są sąsiednie, to odległość planety $\mathrm{B}$ od $\mathrm{C}$ równa się dwóm odległościom planety $\mathrm{A}$ od B. Do planet zalicza się również pas planetoid, będący hipotetyczna planetą; naturalnie planeta A leży bliżej Słońca niż pozostałe. Warto nadmienić przy okazji, że liczba lambda ma się tak do liczby złotej, jak liczba Archimedesa 22/7 do liczby pi; liczba pi jest definiowana przez stosunek obwodu koła do jego średnicy. Liczba złota to nieco mniej niż $62 \%$ całości, natomiast liczba lambda to nieco mniej niż $67 \%$ całości. Lambda jest więc swego rodzaju zaokrągleniem liczby złotej; to zaokrąglenie funkcjonuje w języku codziennym i oznacza zdecydowaną większość. W swoim czasie na Śląsku wybudowano trzy kościoły pokoju i sześć kościołów łaski. Z kościołów pokoju przetrwały dwa, a z kościołów łaski cztery; w obu przypadkach zachowały się 2/3 obiektów. Jest to empiryczne potwierdzenie, jedno z wielu, reguły $2 / 3$. Złotą regułę dowodzi się, korzystając $z$ lematu o forcingu probabilistycznym. Jeżeli zdarzenia $a b$ i $b c$ należą do relacji maksymalnej, to należy pokazać, że zdarzenie ac jest również elementem tej relacji. Oznacza to właśnie przechodniość relacji. Częstotliwość zdarzenia $a b$ i $b c$ jest większa od iloczynu częstotliwości, czyli jest silnie większa od kwadratu liczby złotej. Oznacza to, że częstotliwość zdarzenia ac jest ostro większa od dopełnienia liczby złotej. Z lematu wnosimy, forcing probabilistyczny implikuje forcing częstotliwościowy, że ta częstotliwość jest silnie większa od liczby złotej, a to właśnie należało pokazać. Częstotliwość zdarzenia przeciwnego ca nie może być oczywiście większa od liczby złotej. Jeśli relacje byłyby preferencjami, wtedy oba zdarzenia ac i ca mogą mieć częstotliwość większą od liczby złotej. 
Od kilku lat namawiam kolegów matematyków do opracowania wykładu z przedmiotu zwanego matematyką muzyczną. Moje zachęty, jak na razie, nie znajdują większego zainteresowania tą ideą. Od kolegów uniwersyteckich, biegłych w Internecie, dowiedziałem się, że są już książki i czasopisma poświęcone matematyce muzycznej, z angielska zwanej musical mathematics. Matematyka muzyczna jest przedmiotem łączącym naukę z kulturą i przeznaczonym dla studentów wszystkich specjalności, niezależnie od rodzaju szkoły, w której studiują. Ta osoba, która zrobi dobry wykład matematyki muzycznej, wygra główny los na loterii; będzie rozrywana i proszona do prowadzenia wykładów na wszystkich uczelniach i latach studiów. Piszę to z myślą o ekonometrykach i statystykach, którzy zechcą zainteresować się muzyką z punktu widzenia analizy Fouriera. Badanie sezonowości i tworzenie modeli ekonometrycznych związane jest z funkcjami okresowymi. Nie jest więc stąd daleko do matematyki muzycznej. Dźwięki to fale długie, a kolory to fale krótkie. Można więc pomyśleć o fortepianie z kolorowymi klawiszami, w którym oktawą jest spektrum kolorów, na jakie pryzmat rozkłada światło białe. Gra na takim instrumencie dawałaby i dźwięki, i kolorowy obraz jednocześnie. Świat fizyczny to fale. Wiedział o tym doskonale francuski poeta Arthur Rimbaud. Potwierdza to jego kardynalny w swoim rodzaju wiersz Voyelles - samogłoski. A noir, E blanc, I rouge, U vert, O blue. Notacja muzyczna jest silnie związana $\mathrm{z}$ teorią półgrup. Przez półgrupę słów w skończonym alfabecie rozumie się taką strukturę matematyczną, w której jednością jest słowo puste, a działaniem mnożenie słów, polegające na dopisywaniu słowa do słowa. Słowa określonej długości, czyli zawierające daną liczbę liter, tworzą takty. Kompozycja jest zapisem taktów, tak jak wiersz w poezji lub nowela. Literami w tej półtrupie muzycznej są dźwięki. Takie kompozycje może tworzyć oczywiście komputer lub osoba głucha, która dźwięki utożsamia z odpowiednim drganiem. Wracamy do Renesansu, w którym sztuka i nauka tworzyły jedność.

\section{Literatura}

Łyko J. (2000). Twierdzenie Arrowa a ordynacje wyborcze. [w:] A. Smoluk (red.). Elementy metrologii ekonomicznej. Wydawnictwo Akademii Ekonomicznej we Wrocławiu. S. 165-168.

Smoluk A. (2012). [List ...]. Śląski Przegląd Statystyczny nr 10. Wydawnictwo Uniwersytetu Ekonomicznego we Wrocławiu. S. 114-117. 